\title{
Analisis Pasal 4 Ayat 2 Huruf a Undang-Undang Nomor 1 Tahun 1974 Tentang Perkawinan Terkait Poligami
}

\section{Gede Arya Kusuma1}

1 Program Studi Magister (S2) Kenotariatan Fakultas Hukum Universitas Udayana, BaliIndonesia, E-mail: aryakusuma024@gmail.com

\section{Info Artikel \\ Masuk: 23 Agustus 2019 \\ Diterima :20 Agustus 2019 \\ Terbit : 30 April 2020 \\ Keywords : \\ Marriage; obligation; polygamy}

Kata kunci:

Perkawinan; kewajiban; poligami

\section{Corresponding Author:}

I Gede Arya Kusuma, E-mail: aryakusuma024@gmail.com

DOI :

10.24843/AC.2020.v05.i01.p06

\begin{abstract}
Article 3 paragraph 2 of the Marriage law is stated that in the event that the husband who is about to do the court is able to give permission, but provided that the faterals concerned, in which the marriage law is the principle Open monogamy means not to close the possibility for polygamy. In the event that the husband may do polygamy one of terms is as in article 4 paragraph 2 a states "wives cannot exercise his duty as wife". In that article the word obligation becomes blurred because it is not explained to what extent and what cover the obligation. This writing aims to know what is the condition that the husband can do polygamy and the extent of the wife is said to be unable to exercise her duty as wife as in article 4 paragraph 2 letter a Marriage law. This research is using normative legal research. The conclusion of this writing is that the husband can perform polygamy arranged in article 4 of the Marriage Act as well as the court will still examine the approval of the wife, in terms of marriage as article2 paragraph 1 of the Marriage Act Not escape also from the role of religion and customs, so the obligation of the wife in article 4 paragraph 2 letter A marriage law is also reviewed in terms of indigenous and religious of prospective husband and wife
\end{abstract}

\footnotetext{
Abstrak

Pasal 3 ayat 2 Undang-Undang Perkawinan di nyatakan bahwa dalam hal bilamana suami yang hendak beistri lebih disini pengadilan dapat memberi ijin, namun asalkan di kehendaki fihak-fihak yang bersangkutan, yang di anut Undang-Undang Perkawinan ialah asas monogami terbuka artinya tidak menutup kemungkinan untuk poligami. Dalam hal suami boleh melakukan poligami salah satu syaratnya adalah sebagaimana dalam pasal 4 ayat 2 huruf a menyatakan "istri tidak dapat menjalankan kewajibannya sebagai istri". Didalam pasal tersebut kata kewajiban menjadi kabur karena tidak dijelaskan sejauh mana serta apa saja yang mencangkup kewajiban tersebut. Penulisan ini tujuannya mengetahui apa-apa sajakah yang menjadi syarat suami dapat melakukan poligami dan sejauh mana istri dikatakan tidak dapat menjalankan kewajibannya sebagai istri sebagaimana dalam pasal 4 ayat 2 huruf a Undang-Undang Perkawinan. Penelitian yang penulis gunakan ialah penelitian hukum normatif. Kesimpulan dari penulisan ini adalah suami dapat melakukan poligami diatur dalam pasal 4 Undang-Undang Perkawinan serta pengadilan
} 
masih akan memeriksa persetujuan dari sang istri, dalam hal perkawinan sebagaimana pasal 2 ayat 1 Undang-Undang Perkawinan tidak luput pula dari peran agama serta adat istiadat, sehingga kewajiban istri dalam pasal 4 ayat 2 huruf a Undang-Undang Perkawinan juga ditinjau dari segi adat dan agama kepercayaan calon suami istri

\section{Pendahuluan}

Perkawinan adalah suatu karunia Tuhan yang diberikannya kepada umat manusia sebagai bentuk kecintaannya kepada ciptaannya. Sudah menjadi kodrat dari Tuhan bagi manusia untuk tertarik dan mencintai lawan jenisnya, maka dari hal tersebutlah yang membawa manusia untuk melanjutkan hubungan tersebut dengan suatu ikatan yaitu ikatan perkawinan dan juga sudah merupakan tujuan hidup manusia dari perkawinan itu untuk memperoleh keturunan. Setiap perkawinan yang dilakukan oleh manusia bukan semata-mata hanya karna untuk memenuhi kebutuhan biologis semata namun sebuah perkawinan juga merupakan sebuah kodrat hidup yang dijalankan sebagai manusia. ${ }^{1}$

Perkawinan tidak hanya semata-mata hanya merupakan suatu ikatan diantara dua orang, yaitu pria dengan perempuan yang melangsungkan sebuah ikatan semata, namun juga merupakan ikatan sosial, ikatan perjanjian hukum antar individu dengan segenap keluarga yang akhirnya membentuk sebuah hubungan kekerabatan. Suatu perkawinan biasanya di mulai atau diawali dengan suatu upacara perkawinan, serta perkawinan mempunyai tujuan yaitu untuk membangun satu keluarga yang berbahagia, yang harmonis dan juga kekal serta abadi. ${ }^{2}$

Undang-Undang Republik Indonesia Nomor 1 Tahun 1974 Tentang Perkawinan yang selanjutnya akan disebut Undang-Undang Perkawinan termaktub definisi perkawinan sebagaimana pasal 1 yaitu "Perkawinan ialah ikatan lahir bathin antara seorang pria dengan seorang wanita sebagai suami istri dengan tujuan membentuk keluarga (rumah tangga) yang bahagia dan kekal berdasarkan Ketuhanan Yang Maha Esa." Perkawinan dalam Undang-Undang Perkawinan kita bukan saja sebagai perikatan keperdataan semata namun juga ialah suatu perikatan "keagamaan" artinya bersifat religius hal tersebut dapat diperhatikan dari tujuannya "yaitu membentuk/membangun sebuah keluarga yang bahagia serta kekal abadi berdasarkan Ketuhanan Yang Maha Esa."

Wirjono Prodjodikoro menyatakan bahwa, perkawinan ialah lelaki serta perempuan yang memutuskan untuk hidup bersama dan dengan memenuhi suatu syarat-syarat tertentu, pada dasarnya sebuah perkawinan adalah perjanjian mengikat kedua belah pihak baik lahir maupun bathin yaitu berdasarkan dengan iman. Sayuti Thalib beranggapan bahwa suatu perkawinan ialah perjanjian yang begitu suci diantara seorang lelaki bersama-sama dengan seorang perempuan yang bertujuan untuk membangun sebuah keluarga, dan R. Subekti berpendapat yaitu bahwa suatu

\footnotetext{
1 Santoso, S. (2016). Hakekat Perkawinan Menurut Undang-Undang Perkawinan, Hukum Islam Dan Hukum Adat. Yudisia: Jurnal Pemikiran Hukum dan Hukum Islam, 7(2), 412-434.

2 LAMAN, I., 2017. Perkawinan di bawah umur di KelurahanPurangi Kota Palopo (Doctoral dissertation, Pascasarjana).
} 
perkawinan adalah hubungan yang sah atau suatu pertalian sah pria dengan wanita dalam waktu yang begitu lama. ${ }^{3}$

Dalam pasal 2 ayat 1 Undang-Undang Perkawinan diatur bahwa perkawinan dikatakan sah bilamana diselenggarakan sebagaimana hukum dari masing-masing kepercayaannya/agamanya tersebut. Maka dalam hal perkawinan tidak terlepas dari agama serta adat-istiadat. Sebagai contoh dalam masyarakat Bali, hakekat dari suatu perkawinan sama saja dengan hakekat perkawinan sebagaimana yang dinyatakan didalam Undang-Undang Perkawinan. Perkawinan bukan semata-mata yang bersifat lahiriah namun juga ikatan yang sifatnya rohaniah. ${ }^{4}$ Walaupun Undang-Undang Perkawinan dapat di katakan mengakhiri pluralisme dalam hukum perkawinan adat namun unifikasi hukum perkawinan tetaplah tidak lepas dari agama yang bersangkutan atau yang akan kawin. ${ }^{5}$ Pengaruh agama terhadap adat istiadat juga sangatlah kental dan seakan menjadi satu kesatuan.

Prinsip dari perkawinan yang termaktub di Undang-Undang ialah pembentukan keluarga yang berbahagia yang abadi dan harmonis, pasal 3 ayat 1 pada azasnya didalam ikatan perkawinan, seorang lelaki hanyalah diperbolehkan atau dapat memiliki hanya satu orang istri dan begitupun berlaku sebaliknya serta wanita hanyalah boleh atau dapat mempunyai satu suami. Maka dari hal tersebut yang dianut Undang-Undang Perkawinan yaitu prinsip "Monogami". Namun pada pasal 3 ayat 2 diatur bahwa dalam hal bilamana suami yang hendak beristri lebih disini pengadilan dapat memberi ijin, namun asalkan di kehendaki pihak-pihak yang bersangkutan, dengan terdapatnya pasal tersebut maka yang dianut Undang-Undang Perkawinan ialah asas "Monogami Terbuka" artinya tidak tertutup kemungkinan untuk suami punya istri yang lebih dari satu (poligami).

Dalam pasal 4 ayat (2) Undang-Undang Perkawinan menyatakan bahwa Pengadilan yang sebagaimana dimaksudkan oleh penjelasan ayat (1) di dalam pasal ini sematamata hanya mengizinkan seorang suami atau pria yang berniat untuk memilliki istri lebih dari pada satu bilamana, a. istri tidak dapat melaksanakan kewajibannya sebagai istri; b. istri memperoleh kecacatan di badan atau suatu penyakit yang tak tersembuhkan; c. seorang istri yang tidak bisa melahirkan seorang keturunan.

Suami dapat berpoligami salah satu syarat pada pasal 4 ayat 2 huruf a menyatakan "istri tidak dapat menjalankan kewajibannya sebagai istri". Dalam pasal tersebut kata kewajiban menjadi kabur karena tidak dijelaskan sejauh mana kewajiban tersebut, apa saja yang mencakup kewajiban tersebut sehingga saat tidak dijalankan oleh istri, hal tersebut memenuhi syarat untuk suami dapat berpoligami atau suami dapat beristri lebih dari satu.

Berdasarkan latar belakang tersebut diangkatlah rumusan masalah sebagai berikut: (1) Apa saja yang menjadi syarat suami dapat melakukan poligami?; (2) Sejauh mana istri dikatakan tidak dapat menjalankan kewajibannya sebagai istri sebagaimana dalam pasal 4 ayat 2 huruf a Undang-Undang Nomor 1 Tahun 1974 tentang perkawinan?.

\section{Metode Penelitian}

\footnotetext{
${ }^{3}$ Erwinsyahbana, T. (2012). Sistem hukum perkawinan pada Negara hukum berdasarkan pancasila. Jurnal Ilmu Hukum Riau, 3(01).

4 Wayan P.Windia \& Ketut Sudantra, 2016, Pengantar Hukum Adat Bali, Swasta Nulus, Bali, h. 109

${ }^{5}$ Abubakar, L. (2013). Revitalisasi Hukum Adat sebagai Sumber Hukum dalam Membangun Sistem Hukum Indonesia. Jurnal Dinamika Hukum, 13(2), 319-331.
} 
Penelitian yang penulis gunakan didalam penulisan ini ialah penelitian hukum normatif. Penelitian ini digunakan untuk memecahkan suatu masalah maka didasarkan dengan perundang-undangan serta literature yang ada kaitannya dengan penulisan serta permasalahan ini, yang tentunya akan dibahas dalam penelitian atau penulisan ini, dengan menggunakan landasan-landasan teoritis serta bahan hukum primer dan sekunder. 6 Teknik studi dokumen dikaitkan pada alat yaitu suatu pengumpulan data dimana dilakukan dengan data yang tertulis dengan penggunaan content analysis. 7 Penelitian ini beranjak dari kekaburan norma yaitu mengenai "istri yang tidak dapat menjalankan kewajibannya sebagai istri" yang dimana termaktub dalam pasal 4 ayat 2 huruf a Undang-Undang Perkawinan, sehingga dapat menjadi syarat bagi suami untuk berpoligami atau beristri lebih dari satu.

\section{Hasil Dan Pembahasan}

\subsection{Syarat Suami Dapat Melakukan Poligami}

Poligami ialah seorang suami beristri atau memiliki istri lebih dari satu istri, namun suami itu haruslah dapat berlaku seadil-adilnya ke semua istri-istri yang dimiliki. ${ }^{8}$ Mempunyai istri banyak atau lebih dari satu orang yaitu istilah yang sering di sebut sehari-hari adalah poligami, hal ini sudah dikenal luas di mata masyarakat di dunia. Dari generasi ke generasi, berpoligami terdapat dalam berbagai lingkungan komunitas, hal ini dilakukan baik bangsa di barat maupun di timur. Perkawinan dengan memiliki istri lebih dari seorang ini sudah berlangsung lama dan bahkan jumlah dari istri yang dikawini tersebut pun tidak mengenal batasan. Namun beda dahulu beda juga sekarang apalagi setelah di Undangkannya Undang-Undang mengenai Perkawinan tidak semata-mata seorang suami bebas dalam melakukan poligami, bahkan sampai lebih dari beberapa istri. ${ }^{9}$

Pada dasarnya dalam suatu perkawinan seorang laki-laki/suami hanyalah dapat memiliki satu istri, serta berlaku sebaliknya istri hanya dapat diperbolehkan memiliki satu orang suami, hal itu tercantum di pasal 3 ayat 1 Undang-Undang Nomor 1 Tahun 1974 tentang Perkawinan yang selanjutnya akan disebutkan sebagai Undang-Undang Perkawinan. Namun pada pasal 3 ayat 2, memberi semacam pengecualian yang dimana bahwasannya ijin dapat saja diberikan oleh Pengadilan kepada seorang pria/suami untuk mempunyai istri lebih dari satu asalkan di kehendaki oleh pihakpihak yang bersangkutan. Sebagaimana pasal tersebut mengartikan asas yang teranut dalam Undang-Undang Perkawinan yaitu "Asas Monogami Terbuka" yaitu berarti dimungkinkan di dalam keadaan-keadaan tertentu atau terpaksa suami bisa berpoligami namun poligami tersebut tidak semata-mata bebas atau begitu saja dapat dibuka bebas tanpa adanya suatu pengawasan dari hakim.

Sebenarnya dalam suatu perkawinan, suami hanyalah boleh punya satu seorang istri semata, dan begitu pula seorang wanita hanyalah dapat mempunyai satu orang suami. Tetapi terhadap suami ada pengecualiannya yaitu dalam hal-hal tertentu saja dan juga harus seizin istri/istri-istrinya. Namun bagi si istri tidak berlaku pengecualian tersebut. Sebelum ada Undang-Undang Perkawinan suami bebas dalam hal

\footnotetext{
${ }^{6}$ Krisno, A. A. D. J., Sirtha, I. N., \& Rudy, D. G. (2018). Pencantuman Hak Opsi Perpanjangan Jangka Waktu Sewa Dalam Perjanjian Sewa Menyewa Rumah (Studi Kasus Putusan Pengadilan Negeri Denpasar Nomor 467/Pdt. G/2014/PN. Dps). Acta Comitas: Jurnal Hukum Kenotariatan, 3(2), 233-246. ${ }^{7}$ Soerjono Soekanto, 2014, Pengantar Penelitian Hukum, Universitas Indonesia (UI-PRESS), Jakarta, h. 21

${ }^{8}$ Jamaluddin \& Nanda Amalia, 2016, Buku Ajar Hukum Perkawinan, Unimal Press, Lhokseumawe, h. 50

${ }^{9}$ Muzakki, A. (2016). SOSIOLOGI GENDER: Poligami Perspektif Hukum Islam. Lisan al-Hal: Jurnal Pengembangan Pemikiran dan Kebudayaan, 10(2), 353-372.
} 
melakukan poligami bahkan bebas beristri sampai 4 orang. ${ }^{10}$ Namun sekarang setelah diundangkannya Undang-Undang Perkawinan ada hal-hal atau syarat bilamana ingin beristri lebih dari satu tidak secara semena-mena.

Adapun syarat suami boleh melakukan poligami, suami tersebut wajib memohonkan dan melakukan pengajuan ke pengadilan setempat atau di daerah dimana ia bertempat tinggal sebagaimana pasal 4 ayat (1) Undang-Undang Perkawinan. Lalu didalam pasal 4 ayat (2) merupakan semacam pengecualian, dengan syarat-syarat yang harus terpenuhi didalam pasal 4 ayat 2 tersebut seorang dapatlah berpoligami asalkan terpenuhi syarat tersebut, yaitu istri tidak dapat mejalankan kewajibannya sebagai istri; istri mendapat cacat badan atau penyakit yang tidak dapat disembuhkan; istri tidak dapat melahirkan keturunan. Hal tersebut juga dapat diperhatikan dalam pasal 41 Peraturan Pemerintah Republik Indonesia Nomor 9 Tahun 1975 Tentang Pelaksanaan Undang-Undang Nomor 1 Tahun 1974 Tentang Perkawinan yang selanjutnya disebut PP Nomor 9 Tahun 1975

Alasan-alasan sebagaimana diatas, pengadilan masih akan memeriksa ada maupun tidak adanya persetujuan sang istri, persetujuan bisa berupa lisan ataupun tertulis,jika persetujuan tersebut adalah lisan haruslah dikatakan atau diucapkan di hadapan persidangan. Pengadilan juga akan melihat kemampuan dari pada suami untuk dapat memberikan jaminan untuk terpenuhi keperluan dari istri-istrinya tersebut dan juga anak-anaknya yaitu dengan cara diperhatikannya surat keterangan dari gaji/penghasilan yang telah bertanda tangan bagian keuangan ditempat ia bekerja atau surat - surat yang lain yang dapat diterima oleh hakim dipengadilan. Serta melihat apakah ada tidak jaminan atau indikasi suami akan memperlakukan adil istriistrinya serta anak-anaknya baik itu janji-janji ataupun sebuah pernyataan yang dimana dibuat berbetuk sesuai dengan yang ditetapkan untuk itu. Berlaku adil juga merupakan salah satu syarat yang juga penting dan harus dapat di pertanggung jawabkan oleh seorang suami bilamana berpoligami. Berlaku adil terkait poligami terhadap istri-istrinya juga sangat ditekankan dan ditegaskan dalam hukum agama. Suatu syarat keadilan adalah dimana suami yang akan berpoligami haruslah mampu mewujudkan nilai-nilai serta rasa keadilan dalam suatu keluarga. ${ }^{11}$

Dalam melaksanakan suatu pemeriksaan terkait perihal yang disebutkan diatas, pengadilan juga harus memanggil serta mendengar keterangan dari istri. Dilakukannya pemeriksaan oleh hakim yaitu paling lambatnya adalah 30 hari dari setelah surat permohonan diterima serta lampirannya (pasal 42 PP Nomor 9 Tahun 1975). Dalam hal diperlukannya suatu persetujuan dari istri-istrinya, apabila istri dari yang bersangkutan tidak di mungkinkan untuk dimintai persetujuan misalnya seperti gila ataupun sakit keras, apabila tidak ada kabarnya paling tidak yaitu selambatlambatnya 2 Tahun ataupun karena adanya sebab atau hal lain yang sekiranya perlu dinilai oleh hakim, jadi persetujuan istri tersebut tidak pelu lagi bagi suami sebagaimana pasal 5 ayat (2) Undang-Undang Perkawinan. Bilamana pengadilan berpendapat bahwa sudah cukup alasan suami untuk beristri lebih dari satu, maka diberikanlah putusannya oleh pengadilan yaitu berupa ijin untuk beristri lebih dari seorang sebagaimana pasal 43 PP Nomor 9 Tahun 1975.

Sedangkan untuk Pegawai Negeri Sipil apabila berniat untuk poligami, maka ia wajib melaporkan hal tersebut guna memperoleh ijin dari Pejabat. Pejabat yang dimaksud adalah sabagaimana dalam pasal 1 (b) Peraturan Pemerintah Nomor 10 Tahun 1983

\footnotetext{
${ }^{10}$ Victor Situmorang, 1988, Kedudukan Wanita Di Mata Hukum, PT. Bina Aksara, Jakarta, h. 26

${ }^{11}$ Imron, A. (2012). Menimbang Poligami dalam Hukum Perkawinan. Qistie Jurnal Ilmu Hukum, 6(1).
} 
Tentang Izin Perkawinan dan Perceraian Bagi Pegawai Negeri Sipil yang selanjutnya disebut dengan PP Nomor 10 Tahun 1983 meliputi Menteri; Jaksa Agung; Pimpinan Lembaga Pemerintah Non Departemen; Pimpinan Kesekretariatan Lembaga Tertinggi/Tinggi Negara; Gubernur Kepala Daerah Tingkat 1; Pimpinan Bank Milik Negara; Pimpinan Badan Usaha Milik Negara; Pimpinan Bank Milik Daerah; Pimpinan Badan Usaha Milik Daerah.

\subsection{Analisis Pasal 4 Ayat 2 Huruf a Undang-Undang Nomor 1 Tahun 1974 Tentang Perkawinan Mengenai Istri Dikatakan Tidak Dapat Menjalankan Kewajibannya Sebagai Istri}

Kamus Besar Bahasa Indonesia (KBBI) mengartikan kata kewajiban yaitu dengan arti sesuatu yang wajib dilakukan, keharusan ataupun tugas. Kewajiban merupakan sesuatu atau hal yang harus dikerjakan dengan tanggung jawab. Dalam UndangUndang Perkawinan memang diatur yaitu tentang hak serta kewajiban sebagai pasangan suami istri namun hal tersebut hanya membahas secara umum dan kurang spesifik dalam membahasa kewajiban seorang istri terkait dengan Pasal 4 Ayat 2 huruf a Undang-Undang Perkawinan mengenai istri dikatakan tidak dapat menjalankan kewajibannya sebagai istri. Pasal 30 menyatakan, suami serta istri sama-sama mengemban suatu kewajiban yang luhur guna menegakkan sebuah rumah tangga yang merupakan pilar dasar susunan hidup bermasyarakat. Dalam pasal 31 menyatakan Dalam berumah tangga dan hidup bersama kedudukan serta hak dari pasangan suami istri adalah sama atau seimbang; Baik suami maupun istri mempunyai hak untuk melakukan upaya atau perbuatan hukum; Suami merupakan kepala dari keluarga sedangkan istri merupakan ibu rumah tangga.

Selanjutnya dalam pasal 33 menyatakan pasangan suami istri wajib untuk saling cintamencintai satu sama lainnya,saling menghormati, memberi bantuan baik bantuan lahir maupun bathin satu sama lain, hal itu sudah tertera jelas dan sudah barang pasti sebagai kewajiban antara keduanya. Kewajiban soerang Istri yaitu harus dapat mengatur urusan rumah tangganya dengan baik sebagaimana diatur dalam pasal 34 . Namun terdapat kekurang jelasan serta mengkhusus dalam pasal tersebut yang mengatur kewajiban-kewajiban istri karena tidak menyatakan kewajiban istri secara khusus serta kurang dijabarkan apa saja yang mencakup kewajiban istri, sehingga memenuhi unsur dalam pasal 4 ayat (2) huruf a Undang-Undang Perkawinan yang mana istri tidak dapat menjalankan kewajiban sebagai istri dan adanya suatu kepastian hukum.

Sebagaimana teori kepastian hukum yaitu suatu aturan dari hukum, baik itu adalah aturan yang tertulis yaitu undang-undang maupun hukum yang tidak tertulis, haruslah dapat menjadi pedoman bagi seseorang dalam berperilaku di dalam bermasyarakat, maka dari itu haruslah terdapat aturan umum untuk menjadi pedoman. Baik untuk hubungan sesama individu maupun individu dengan masyarakat, maka akan timbul kepastian hukum. Kepastian hukum guna mengetahui suatu perbuatan individu, bertingkah laku mana saja yang boleh dan serta yang tidak boleh untuk diperbuat. ${ }^{12}$ Sehingga aturan harus jelas guna memberikan kepastian hukum.

Dalam hal perkawinan sebagaimana telah di atur dalam Undang-Undang Perkawinan sebuah perkawinan tidak luput pula dari peran agama serta adat istiadat yang bersangkutan, kedua belah pihak baik suami dan istri. Maka hal tersebut untuk mengetahui hak serta kewajiban dari suami dan istri terutama dalam membahas

\footnotetext{
${ }^{12}$ Peter Mahmud Marzuki, 2008, Pengantar Ilmu Hukum, Kencana Prenada Media Group, Jakarta, h. 158
} 
mengenai 4 ayat 2 huruf a Undang-Undang Perkawinan yaitu istri tidak dapat menjalankan kewajiban sebagai istri. Perlu ditinjau juga dari sudut pandang adat dan juga agama sebagaimana perkawinan tidak luput dari adat dan agama sebagaimana pasal 2 ayat 1 Undang-Undang Perkawinan yang dimana bilamana perkawinan tersebut dilaksanakan sebagaimana menurut agamanya serta kepercayaanya maka perkawinan tersebut adalah sah.

Dalam hukum adat pada umumnya kewajiban dalam menegakan keluarga atau rumah tangga bukan hanya semata-mata menjadi tanggung jawab atau kewajiban suami istri tersebut saja, namun masih terdapat tanggung jawab serta kewajiban dari orang tua dan juga kerabat walaupun hal tersebut bersifat tidak langsung yaitu berupa perhatian, berupa pengawasan apalagi keluarga tersebut masih baru ataupun pasangan suami istri yang berumur muda. Dalam hal Hak dan kewajiban dalam hukum adat untuk perkawinan yaitu bentuknya adalah suatu perkawinan yaitu dengan pembayaran jujur yang dimana mempertahankan keturunan yaitu dari garis keturunan laki-laki menjadikan hak dan kedudukan istri menjadi berbeda, istri harus mematuhi suami dan juga kerabat dari suami, serta semua hal atau sesuatu harus diselesaikan yaitu dengan cara musyawarah bersama-sama kerabat, istri membantu dalam mengatur kehidupan berumah tangga serta mengatur hubungan dengan kerabat-kerabat atau didalam pergaulannya sehari-hari dalam masyarakat, itupun hanya bilamana "istri ratu" untuk suami yang beristri lebih dari seorang. ${ }^{13}$

Dalam hukum adat yang seperti sekarang kebanyakan telah fleksibel artinya menyesuaikan dengan jaman sekarang. Ia pun tidak melarang lagi perempuan yang hendak pergi keluar rumah dengan bebas, dalam hal perbuatan hukum keduanya yaitu suami istri berhak untuk berbuat, istripun bebas pergi atau berbelanja ke pasar, istri berjualan/jual beli, berdagang keliling, bekerja di kantoran, menunggu sebuah kedai, menjadi kepala desa, bahkan menjadi tentara atau polisi. Namun untuk hal-hal tertentu yaitu yang menyangkut dengan adat, seperti misalnya perihal harta benda atau kekayaan adat, bangunan atau rumah adat, ataupun tanah adat seorang istri tidak mempunyai hak untuk melakukan tindakan atau berbuat sendiri, tanpa persetujuan dari suaminya serta tanpa persetujuan dari kerabatnya. ${ }^{14}$

Hukum agama mengatur pula mengenai kewajiban seorang istri. Dalam Agama Hindu selain kewajiban istri diatur pula mengenai kewajiban suami. Adapun kewajiban pasangan suami serta istri tersebut tertuang di dalam Manu Dharmasastra (Weda Smrti) yaitu Bab IX dalam pasal 1 sampai dengan 103. Adapun beberapa kewajiban istri yaitu meliputi istri sebagai seorang wanita yaitu hendak terus menerus untuk selalu usaha-berusaha bersama-sama tidak individual apalagi hendak meninggalkan suaminya; Istri juga harus pintar-pintar membawa dirinya dan mampu dalam mengatur, merawat serta turut memelihara sebuah keluarga yang baik dan juga ekonomis; istri haruslah setia kepada suaminya dan hendaknya untuk selalu berusaha supaya tidak melanggar apa yang diamanatkan dalam kitab suci, bilamana istri melanggar maka ia berdosa; Istri harus megendalikan pikiran, tingkah laku dan perkataan dengan ingat selalu kepada Tuhan serta kebajikan dan ingat selalu pada suami, seorang istri wajib memelihara rumah tangga bilamana istri ditinggalkan oleh suami dikarenakan ada pekerjaan/tugas keluar daerah, apabila suami tidak

\footnotetext{
${ }^{13}$ Hilman Hadikusuma, 2007, Hukum Perkawinan Indonenesia Menurut: Perundang-undangan, Hukum Adat, Hukum Agama, Mandar Maju, Bandung, h.104

14 Ibid, h. 105
} 
memberikan nafkah istri dapat bekerja guna menunjang hidupnya asalakan pekerjaan tersebut sesuai dan sejalan dengan norma-norma dari kesopanan seorang wanita. ${ }^{15}$ Dalam Hukum Islam, ada hal atau substansi yang tidak diatur dalam Undang-Undang Perkawinan tapi dalam Hukum Islam hal tersebut merupakan hal yang amat penting. Yaitu suami atau istri berkewajiban untuk saling menjaga dan menjunjung kehormatan diri dan keluarga, serta menyimpan rahasia suami maupun keluarga. Dalam Al Quran "wanita yang saleh, ialah yang taat kepada Allah dan memelihara diri di balik pembelakangan suaminya, oleh karena alloh memelihara mereka" yang berarti istri tidaklah boleh melakukan kecurangan serta memelihara kehormatan dan harta benda suami dan juga hartanya sendiri. Dalam hadis riwayat Ahmad dan Muslim dituangkan bahwa Nabi SAW berkata bahwa menurut agama Islam dilarang keras tidak menjaga rahasia alias membeberkan rahasia keluarga terutama dalam hal rahasia di tempat tidur. Jika seorang suami memenuhi kewajiban menjadi seorang suami seperti memberikan nafkah secara lahir bathin maka istri harus tunduk pada kemauan suami yang layak, bila tidak nusyus (tidak menurut) istri tidak mendapatkan nafkah.

Bagi agama Kristen/Katolik yang diatur dalam pasal 45-48 HOCI stb. 1933:74 yang setidak-tidaknya merupakan pencerminan dari ajaran agama Kristen. Suami istri harus saling setia tolong menolong serta bela membela, memelihara serta mendidik anak dengan baik. Dalam Katolik suami istri memiliki hak serta kewajiban yang sama, begitu pula sebagai orang tua mengusahakan pendidikan anak anak baik fisik sosial, kultural serta religious. Jadi suami istri bersama-sama mengurus kehidupan sehingga suami istri benar-benar menjadi satu kesatuan baik itu dalam pikiran, perasaan maupun kehendak.

Dalam agama Budha hak serta kewajiban suami maupun istri telah disesuaikan dengan Undang-Undang Perkawinan dalam Hukum Perkawinan Budha (HPAB) tahun 1977 salah satunya adalah yang diatur dalam pasal pasal 32 HPAB menyatakan istri yang baik wajib berlaku ramah terhadap keluarga kedua pihak, wajib setia dengan suaminya serta melindungi milik suaminya serta wajib rajin dalam mengurus pekerjaan. Suami istri juga wajib saling menghormati, saling membantu baik lahir maupun bathin, sehingga tercapailah maksud serta tujuan dari perkawinan itu sendiri yaitu membangun satu keluarga yang harmonis dan bahagia.

Menurut H. Hilman Hadikusuma dalam pasal 4 ayat 2 Undang-Undang Perkawinan menyatakan Pengadilan sebagaimana yang dimaksudkan di ayat (1) bahwa pengadilan dapat memberi ijin suami yang berniat berpoligami bilamana: istri tidak dapat menjalankan kewajibannya sebagai istri; istri terdapat kecacatan di badannya ataupun suatu penyakit yang tidak mampu tersembuhkan; istri tidak mampu menghasilkan keturunan. "Tidak dapat menjalankan kewajibannya sebagai istri" misalkan dalam hal suaminya tidak dilayani maupun didampingi dengan baik, tidak merawat keluarga dengan baik, tidak mendidik serta terurusnya anak dengan baik, serta tidak dapat menjaga kehormatannya sebagai seorang perempuan misalkan maksiat, berzina, pemabuk dan berjudi. ${ }^{16}$

\section{Kesimpulan}

Syarat suami untuk dapat melakukan poligami wajib mengajukan permohonan ke pengadilan setempat sebagaimana pasal 4 ayat 1 Undang-Undang Perkawinan. Pengadilan yang mana dimaksudkan dalam pasal 4 ayat 1 hanya memberikan ijin kepada seorang suami yang ingin berpoligami bila memiliki alasan sebagaimana pasal

\footnotetext{
${ }^{15} \mathrm{Ibid}$, h. 111

${ }^{16} \mathrm{Ibid}$, h. 33
} 
4 ayat 2. Pengadilan juga akan memeriksa sang istri terkait persetujuanya. Namun apabila istri dari yang bersangkutan tidak di mungkinkan untuk dimintai persetujuan misalnya seperti gila, sakit keras, tidak ada kabarnya paling tidak selambat-lambatnya 2 Tahun, atau karena adanya penyebab atau hal lain yang sekiranya perlu dinilai oleh hakim, jadi persetujuan istri tersebut tidak perlu lagi bagi suami sebagaimana pasal 5 ayat (2) dan untuk Pegawai Negeri Sipil harus mendapat ijin dari pejabat, pejabat yang di maksud sebagaimana pasal 1 (b) PP Nomor 10 Tahun 1983.

Pasal 30, 33 dan 34 Undang-Undang Perkawinan mengatur mengenai kewajiban dari suami istri namun masih terlalu umum. Sebagaimana perkawinan dinyatakan pasal 2 ayat 1 perkawinan tidak luput dari peran agama, sehingga untuk meninjau kewajiban istri dalam pasal 4 ayat 2 huruf a maka juga harus ditinjau dari segi agama, adat atau kepercayaan pasangan suami istri tersebut. Menurut H. Hilman Hadikusuma "tidak dapat menjalankan kewajibannya sebagai istri" dalam pasal 4 ayat 2 huruf a UndangUndang Perkawinan adalah tidak mendampingi dan melayani suaminya dengan baik, tidak mengatur atau merawat rumah tangga dengan baik, tidak mendidik serta terurusnya anak dengan baik serta tidak dapat menjaga kehormatannya sebagai seorang perempuan misalkan maksiat, berzina, pemabuk dan berjudi.

\section{Daftar Pustaka / Daftar Referensi}

Buku:

Hadikusuma, H. (2007). Hukum Perkawinan Indonenesia Menurut: Perundang-undangan, Hukum Adat, Hukum Agama. Mandar Maju.

Jamaluddin \& Amalia, N. (2016). Buku Ajar Hukum Perkawinan. Unimal Press.

Marzuki. P. (2008). Pengantar Ilmu Hukum. Kencana Prenada Media Group.

Soekanto, S. (2014). Pengantar Penelitian Hukum. Universitas Indonesia (UI-PRESS).

Situmorang, V. (1988). Kedudukan Wanita Di Mata Hukum. PT. Bina Aksara.

Windia, W \& Sudantra. K. (2016). Pengantar Hukum Adat Bali. Swasta Nulus.

\section{Jurnal:}

Abubakar, L. (2013). Revitalisasi Hukum Adat sebagai Sumber Hukum dalam Membangun Sistem Hukum Indonesia. Jurnal Dinamika Hukum, 13(2), 319-331.

Erwinsyahbana, T. (2012). Sistem hukum perkawinan pada Negara hukum berdasarkan pancasila. Jurnal Ilmu Hukum Riau, 3(01).

Imron, A. (2012). Menimbang Poligami dalam Hukum Perkawinan. Qistie Jurnal Ilmu Hukum, 6(1).

Krisno, A. A. D. J., Sirtha, I. N., \& Rudy, D. G. (2018). Pencantuman Hak Opsi Perpanjangan Jangka Waktu Sewa Dalam Perjanjian Sewa Menyewa Rumah (Studi Kasus Putusan Pengadilan Negeri Denpasar Nomor 467/Pdt. G/2014/PN. Dps). Acta Comitas: Jurnal Hukum Kenotariatan, 3(2), 233-246.

Muzakki, A. (2016). SOSIOLOGI GENDER: Poligami Perspektif Hukum Islam. Lisan alHal: Jurnal Pengembangan Pemikiran dan Kebudayaan, 10(2), 353-372.

Santoso, S. (2016). Hakekat Perkawinan Menurut Undang-Undang Perkawinan, Hukum Islam Dan Hukum Adat. Yudisia: Jurnal Pemikiran Hukum dan Hukum Islam, 7(2), 412-434.

Tesis/Disertasi:

LAMAN, I., 2017. Perkawinan di bawah umur di KelurahanPurangi Kota Palopo (Doctoral dissertation, Pascasarjana).

Peraturan Perundang-Undangan:

Undang-Undang Republik Indonesia Nomor 1 Tahun 1974 Tentang Perkawinan Lembaran Negara Republik Indonesia Tahun 1974 Nomor 1. 
Peraturan Pemerintah Republik Indonesia Nomor 9 Tahun 1975 Tentang Pelaksanaan Undang-Undang Nomor 1 Tahun 1974 Tentang Perkawinan Lembaran Negara Republik Indonesia Tahun 1975 Nomor 12

Peraturan Pemerintah Republik Indonesia Nomor 10 Tahun 1983 Tentang Izin Perkawinan dan Perceraian Bagi Pegawai Negeri Sipil Lembaran Negara Republik Indonesia Tahun 1983 Nomor 13 